УДК 37.01:81’27

DOI: 10.37026/2520-6427-2019-100-4-96-100
Леся ЗАВОДНА,

методист кабінету редакиійно-видавничої діяльності

Рівненського ОІППО, магістр філологї̈

\title{
НЕОЛОГІЗМИ, \\ ВИНИКНЕННЯ ЯКИХ ЗУМОВЛЕНО СУЧАСНИМИ МОДЕРНІЗАЦІЙНИМИ ПРОЦЕСАМИ У ВІТЧИЗНЯНІЙ ОСВІТІ
}

У статті простежено зв'язок між сучасними суспільними процесами та появою в украӥнській мові новотворів. Охарактеризовано нові й актуалізовані слова та значення, виникнення яких зумовлено модернізаційними процесами у вітчизняній освіті.

Ключові слова: неологізми, нові й актуалізовані слова та значення, модернізаційні прочеси в освіті.

В статье прослеживается связь между современными общественными прочессами и появлением в украинском языке новообразований. Охарактеризованы новые и актуализированы слова и значения, возникновение которых обусловлено модернизационными прочессами в отечественном образовании.

Ключевые слова: неологизмы, новые и актуализированы слова и значения, модернизачионнье проиессы в образовании.

A striking example, which demonstrates the dynamic character of language, is the innovative lexical-semantic processes that demonstrate the absolute progress associated with the realization of new capabilities of the language system, including word formation.

Therefore, it is appropriate to consider Wilhelm von Humboldt's view that "the vocabulary of a language cannot be regarded as stiffened and changeless mass, as it is a constant process new words formation. The vocabulary remains the product of word-forming potential that develops and reproduces again, as long as the language exist as live speech of the people».

Thus, the formation of a significant number of neologisms in the modern Ukrainian literary language is an objective process of linguistic progress, without which any language is difficult to imagine today.

Modernization of educational activity in Ukraine in the 21 st century provides a number of key problems have to be solved: ensuring formation of a person with innovative thinking and culture, capable to innovative activity; affirmation principle of child-centrism in education; transition to tolerant pedagogy; preparation Ukrainian citizens for life in the conditions of global space, formation some kind of "globalist person»; education of the citizens of Ukraine of a modern system of values that would contribute to the maximum self-realization of each of them, affirmation of national unity.

All above steps are accompanied by the emergence of new terms and names that are inherent in this process of new words, which in our study we will refer to as «neologisms of a New Ukrainian School».

Key words: neologism, new updated words and meanings, modernization processes in education.

Нова доба нового прагне слова. Максим Рильський

Суспільство створює всі умови для певних мовних змін і стимулює мовні процеси, що призводять до задоволення його нових потреб як у номінації, так і в комунікації. Лексичний склад мови надзвичайно чутливий до тих змін, що відбуваються в житті творця й носія мови - народу. Саме тому всі зміни, які мають місце в житті суспільства, найбільш виразно віддзеркалено в лексичній системі мови. Кожне нове суспільне явище, процес, дія, кожне нове поняття вимагає свого найменування, тобто свого означення [10].

Яскравими зразками, що засвідчують динамічний характер мови, є інноваційні лексико-семантичні процеси, що демонструють абсолютний прогрес, пов'язаний із реалізацією нових можливостей мовної системи, зокрема й словотвірних. Доречним у зв'язку з цим нам видається міркування Вільгельма фон Гумбольдта про те, що «словниковий запас мови у жодному разі не можна розглядати як готову, застиглу масу, не кажучи вже про постійний процес утворення нових слів і словоформ. Словниковий запас, допоки мова живе в мовленні народу, залишається продуктом словотвірної потенції, який розвивається і знову відтворюється» [3, с. 112].

Таким чином, народження в сучасній українській літературній мові значної кількості неологізмів є об'єктивним процесом мовного прогресу, без якого важко уявити сьогодні будь-яку мову, зокрема й українську. 
Аналіз наукових досліджень і публікацій. Інновації в українській лексиці неодноразово досліджувалися на різних часових зрізах такими мовознавцями, як: В. Коломієць, А. Москаленко, О. Муромцева, А. Нелюба, В. Присяжнюк, Ю. Редько, О. Стишов, Л. Струганець, О. Тараненко, О. Терещенко, І. Шашкін, Г. Вокальчук, Н. Адах, Н. Гаврилюк, О. Тимочко та ін. Питаннями стосовно місця нових слів у системі мови, принципів їх творення, класифікації, функціонування займалися I. Ковалик, Н. Клименко, М. Плющ, Н. Москаленко, А. Медушевський, І. Матвіяс, А. Грищенко, I. Ющук, О. Тараненко, В. Горпинич, О. Сербенська, І. Білодід, А. Коваль, О. Пономарів та ін.

Однак варто зауважити, що питання появи нових слів і виразів, спричинених сучасними модернізаційними процесами у вітчизняній освіті, досі науковцями не розглядалося, що і послужило написанню нами означеної статті.

Мета статті - окреслити причини появи в українській мові новотворів, виникнення яких зумовили модернізаційні процеси у вітчизняній освіті, зокрема прийняття Концепції «Нова українська школа».

Виклад основного матеріалу. 14 грудня 2016 p. Кабінетом Міністрів України було схвалено Концепцію Нової української школи [8], яка є стратегічною основою для подальшої діяльності уряду щодо реформування середньої освіти. Як наслідок - у сучасній українській педагогічній теорії стало помітним неабияке захоплення новим напрямом досліджень «нова украӥнська школа». У чому його суть? У зв'язку з цим сучасна українська дослідниця та науковець М. Скрипник стверджує, що «термін «украӥнська икола», фактично, вживається в різних сенсах.

По-перше, він означає освіту певної нації в іншому вимірі, протилежному до освіти іншого - етнічного або й позаетнічного культурного середовища. По-друге, означуваний термін скрізь, від самої своєї появи, вживається як школа певною національною мовою, тобто йдеться про щось специфічно національне в школі певної нації. По-третє, «нова українська школа» - це проблема співвідношення інноваційності та консервативності в украӥнській школі, що термінологічно акцентовано в понятті «нова». Тобто йдеться про те, що в українській школі не забувають iii основні історичні здобутки, ... стверджують вітчизняну школу через творче змагання з освітніми архіпрактиками світового рівня...» [10].

Таким чином, сучасне українське суспільство, переходячи до «нової української школи», неодмінно змушене буде пройти і крізь непростий етап модернізаційних змін, який, за влучним висловом ученого М. Михальченка, «є проєктом, що ніколи не завершується в глобальному вимірі, адже суспільство, яке завершило модернізаційний проєкт, може вирушати на історичний смітник» [6, с. 19].

Модернізація освітньої діяльності в Україні в XXI ст. передбачає розв'язання низки ключових проблем: забезпечення формування інноваційної людини 3 інноваційним мисленням, інноваційною культурою, здатної до інноваційної діяльності; утвердження в освіті принципу дитиноцентризму; перехід до толерантної педагогіки; здійснення підготовки громадянина України до життя в умовах глобального простору, формування своєрідної глобалістської людини; виховання у громадян України сучасної системи цінностей, що сприяли б максимальній самореалізації кожного з них, утвердженню національної єдності [9].
Усі означені вище кроки, звичайно, супроводжуються появою нових слів і значень, притаманних для цього процесу, які ми у нашому дослідженні називатимемо «новотворами нової украӥнської иколи». Розглянемо їх детальніше, а для зручності об'єднаємо у своєрідні тематичні групи, які представимо нижче.

Формула нової української школи

- «Автономія школи" - школи зможуть самостійно формувати освітні програми, складати навчальні плани і програми із навчальних предметів; керівника школи обиратимуть на конкурсних засадах терміном до п'яти років, він зможе обіймати посаду не більше як два терміни поспіль.

- "Децентралізація" - передача значних повноважень та бюджетів від державних органів органам місцевого самоврядування.

- «Дитиноцентризм» - модель виховання та навчання дитини, призначення якої - максимальне наближення навчання і виховання конкретної дитини до іiі сутності, здібностей і життєвих планів, розширення ії життєвого шляху та саморозвитку, увага до системи іiї цінностей та інтересів задля формування в неї основ життєвої компетентності.

- «Глобалістське мислення» - можливість повною мірою бачити переваги і недоліки попередніх рівнів, об'єднуючи їх у єдину цілісність.

- «Інноваційна людина» - особистість 3 активною життєвою позицією, спроможна не лише просто існувати, а й активно працювати в умовах інформаційного суспільства.

"Ключові компетентності» («компетентності для жстття») - спеціально структурований комплекс характеристик (якостей) особистості, що дає їй можливість ефективно діяти у різних сферах життєдіяльності та належить до загальногалузевого змісту освітніх стандартів: уміння вчитися, спілкуватися державною, рідною та іноземними мовами, математична і базові компетентності в галузі природознавства і техніки, інформаційно-комунікаційна, соціальна, громадянська, загальнокультурна, підприємницька і здоров'язбережувальна компетентності).

- «Нове освітне середовище» - стосується не лише зміни формату стосунків між учнем, батьками та вчителем, а й організації простору та класу: крім класичних варіантів буде використано новітні, наприклад, мобільні робочі місця, які легко переорієнтовувати для групової роботи.

- «Новий випускник» - випускник НУШ: цілісна особистість (усебічно розвинена, здатна до критичного мислення); патріот з активною позицією (діє згідно 3 морально-етичними принципами, здатний приймати відповідальні й виважені рішення); інноватор (здатний змінювати навколишній світ, розвивати економіку конкурувати на ринку праці, вчитися впродовж усього життя).

- «Новий зміст освіти» - заснований на формуванні компетентностей, необхідних для успішної самореалізації в суспільстві.

- «Педагогіка партнерства» - являє собою систему методів і прийомів виховання і навчання на засадах гуманізму та творчого підходу до розвитку особистості, формується на подоланні інертності мислення, переході на якісно новий рівень побудови взаємовідносин між усіма учасниками освітнього процесу: учнем, учителем і батьками.

- «Педагогіка толерантності»-педагогіка, головним завданням якої є розвиток здатності до терпіння, 
витримки, самоконтролю та вміння вирішувати мирним шляхом суперечності та конфлікти в освіті, створення соціально-педагогічних умов толерантної взаємодії, культури спілкування, оскільки толерантність $\epsilon$ гарантією суспільної стабільності.

- «Рівний доступ до якісної освіти» - передбачає урахування гендерних, соціальних, національних, політичних, релігійних, матеріальних особливостей та їх особливих потреб;

- «Умотивований учитель» - той, що має свободу творчості й розвивається професійно;

- "Наскрізні компетентності» - вміння вчитися, здоров'язбережувальна, загальнокультурна (комунікативна), соціально-трудова, інформаційна.

- «Сучасне освітнє середовище» - система впливів та умов формування особистості, а також можливостей іiі розвитку, які містяться в соціальному та просторово-предметному оточенні. Навчання будьде, будь-коли, будь-яке, 3 максимальною користю особисто для кожного - таким воно має бути [5].

Неологізми, що увійшли в учнівське середовище нової української школи

- «Загальні очікувані результати» (ЗОРи) - вказують на рівень розвитку кожного вміння на завершення циклу (1-2 класи і 3-4 класи).

- «3містові лінії» - відображають зміст кожної освітньої галузі, окреслюють ії внутрішню структуру, систематизують конкретні очікувані результати галузі.

- "Конкретні очікувані результати» (КОРи) визначають обов'язковий зміст, «ядро знань», через який відбувається розвиток умінь згідно із загальними цілями відповідних галузей. Кожен КОР пов'язаний із загальною ціллю і загальним очікуваним результатом за допомогою системи індексів. КОРи впорядковуються в логічній послідовності за тижнями.

- «Модельна навчальна програма» - створюється на основі Стандарту початкової освіти експертною спільнотою і затверджується Міністерством; вона містить: перелік освітніх галузей і навчальних предметів; завдання для педагога, які він ставить перед собою в рамках тижня, а також знання і вміння учнів (безвідносно до галузей) після розгляду проблемних запитань; засоби оцінювання навчальних досягнень учнів.

- «Модифікації освітнього процесу» - зміни, що стосуються змісту навчання (менша складність, менший обсяг навчального матеріалу), зумовлені особливостями розвитку дитини.

- «Навчальні центри» - осередки, які відображають навчальні потреби й інтереси дітей, наприклад: навчальний центр; центр відпочинку; центр творчості; ігровий центр; бібліотечний (читацький) центр; музичний центр; інформаційний центр тощо. Вони містять різні навчальні матеріали, які змінюються відповідно до тематичного планування, індивідуальних потреб дітей.

- «Ранкові зустрічі» («ранкове коло») - це заплановані, структуровані зустрічі тривалістю 15-25 хв. на початку дня учнів класу з педагогом, у ході яких діти діляться власним досвідом з однолітками, ставлять запитання та коментують відповіді; обмінюються новинами; позитивно налаштовуються на новий день.

- Ротаційні моделі "Щоденні 5» (читання $i$ письмо) $\boldsymbol{i}$ «Щоденні 3» (математика) - щоденні діяльності, виконуючи які, діти навчаються бути самостійними під час читання, письма й математики, в той час як учитель має можливість працювати з учнями індивідуально та в малих групах.
- Технологія "Читання та письмо для розвитку критичного мислення» (Reading and Writing for Critical Thinking - ЧПКМ) - створена для задоволення потреби школи в організації активного навчання та для забезпечення розвитку критичного мислення учнів на уроках читання та письма [7].

- «Право на помилку» - дає дитині усвідомлення того, що оцінка - це не покарання, а передусім ціль, до якої потрібно прямувати. При цьому помилка - це складова пізнання і дослідження, а відсутність страху помилки - запорука того, що дитина залишатиметься вмотивованою, навіть якщо їй щось не вдаватиметься 3 першого разу.

Учитель нового покоління

- «Агент змін» - мотивовані педагоги, які готові до змін в освіті; вчителі, що надихають;

- «Новий учитель» - психологічно та емоційно компетентна людина, лідер і менеджер, хороший професіонал, вільний від стереотипів, ефективний комунікатор, агент змін, успішний фахівець, людина-лідер, що може вести за собою, не лише любить свій предмет, а й фахово його викладає формує знання та навички, потрібні в сучасному світі.

- «Нова роль учителя» - він не лише єдиний наставник та джерело знань, а насамперед - коуч, модератор, ментор, новатор, супервізор, тьютор, фасилітатор в індивідуальній освітній траєкторії дитини: коуч - той, хто допомагає досягти життєвої або професійної мети. Він сприймає людину такою, якою вона $є$ насправді, а не оцінює iї; модератор - людина, яка проводить соціологічні дослідження, ведучий фокус-групи, адміністратор форуму, чату, соціальної мережі в Інтернеті, той хто налагоджує комунікативну взаємодію у класі, організує рефлексію, проектує наступні кроки в освіті; ментор - досвідчений і надійний товариш, порадник, наставник) - той, що є наставником; новатор - педагог, який приносить в інтелектуальну освітню діяльність нові ідеї; супервізор - фахівець із високим рівнем кваліфікації та успішним досвідом роботи, який здійснює свою діяльність із метою професійної підтримки та професійного розвитку педагогічних працівників, тренерів і тренерів-педагогів, сприяє налагодженню партнерства між усіма учасниками освітнього процесу в умовах реформування системи освіти, впровадження Концепції Нової української школи; тьютор - той, що індивідуально працює 3 інтересом дитини - виявляє освітні запити, проектує освітню діяльність, організує рефлексію, проектує наступні кроки в освіті; фасилітатор - підтримує дитину в іiі навчальній діяльності через педагогічну взаємодію, допомагає, надихає [8].

Методики-новотвори, що полегшують засвосння знань і роблять навчальний процес цікавим і захоплюючим

- «BYOD» (принеси свій пристрій) - можливість використання на уроці власних пристроїв, дозволяє вчитись у будь-який час і де завгодно Більше не потрібно шукати комп'ютер, маючи власний пристрій, можна негайно приступити до навчання.

- "E-LEARNING» (електронне навчання, навчання у мережі, онлайн-навчання) - в основу такого навчання покладено відкритість освітніх ресурсів, децентралізація навчальної діяльності та використання інформаційних технологій таке навчання спонукає суспільство до освіти та самоосвіти.

- "OER» (Open Educational Resources - вiдкриmi освітні ресурси) - цифрові навчальні матеріали, 
що викладаються для публічного доступу, як-от: підручники, конспекти лекцій, різноманітні відеокурси, навчальні журнали, публікації тощо. Сам факт подання власних матеріалів для публічного доступу - значний крок у розвитку як для окремої людини, так 1 закладу освіти.

- «STEM-освіma» (3 англійської - Science (Наука); Technology (Технологіï); Engineering (Інженерія); Math (Математика)) - процес формування та розвитку розумово-пізнавальних і творчих якостей дітей, коли дисципліни вивчаються не окремо, а в комплекci; важливим є практичне застосування знань, коли діти вчаться реалізовувати вивчене на практиці.

- «Активне навчання" - передбачає практичне застосування навичок отриманих в процесі навчально-пізнавальної діяльності (у формі ігор, тренінгів, проведення різноманітних досліджень, створення колективних проектів).

- «Воркшоп» - колективний навчальний захід, учасники якого отримують нові знання та навички в процесі динамічної групової роботи.

- «Іарове навчання» - навчання з використанням різноманітних ігор (комп'ютерних, рольових, ділових рухливих, настільних тощо).

- «Квест» - ігрова технологія, при реалізації якої відбувається процес виконання учнями навчальних, пошуково-пізнавальних, проблемних завдань відповідно до ігрового задуму/сюжету, коли діти добирають та впорядковують інформацію, виконують дослідницьку, самостійну роботу, що сприяє систематизації та узагальненню вивченого матеріалу. Серед різновидів: веб-квести, бібліотечні квести, медіаквести, квести-змагання та ін.

- «Кейс-уроки» (кейс-стаді) - навчальний матеріал, структурований за особливим алгоритмом. Заняття складається із 6-ти або 10-ти розгорток, які об'єднані головною темою кейса. Моделі кейса розробляють на основі життєвих ситуацій. Кейс-уроки дають учням можливість самостійно організовувати процес засвоєння матеріалу, мотивують до роботи, зокрема і групової, з різними джерелами інформації.

- «Метод асоціативних символів" - це кодова мова жестів, рухів, міміки, уявлень і асоціацій, максимально наближена до реальності.

- «Перевернутий клас» - концепція «перевернутого класу» передбачає навчання «навпаки»: зазвичай у школі слухають учителя, а вдома виконують завдання; у цій концепції учні вдома ознайомлюються із навчальним матеріалом, а в школі працюють над завданнями та беруть участь в обговоренні.

- «Проблемно оріснтоване навчання" - знання здобуваються учнями завдяки вирішенню реальних життєвих ситуацій на основі використання достовірних джерел і колективних обговорень; учитель виступає у ролі наставника-консультанта.

- "Проектне навчання" - використовується не лише для побудови проектів, а й для побудови ситуацій, що стимулюють дослідницький і творчий дух учнів. При цьому учитель виступає у ролі наукового керівника.

- «Цифрове суспільство" - можливість брати участь в онлайн-співтовариствах. Сьогодні ми всі $є$ учасниками онлайн-співтовариства, яке поступово перетворюється на повноцінне глобальне співтовариство [2, с. 72-77].

Представлені нами новотвори, насамперед «нова українська школа», «нове освітнє середовище», «дитиноцентризм», «наскрізні компетентності», «педагогіка партнерства», «учитель нового покоління» та інші, не лише осучаснюють, збагачують, модернізують український освітній простір, дають назви новим явищам, що виникають сьогодні в освіті, а й доводять, що сучасна українська освіта невіддільна від змін у системі «культура - суспільство - нація». Ще вчора нові, сьогодні вони стають загальновживаними і вже, як не дивно, ні в кого не викликають запитань щодо свого потрактування, не «ріжуть вухо», а навпаки - навіть викликають певний захват.

Аргументованою взаємозумовленістю змін цих елементів є мова в іiі пізнавальних і цивілізаційних параметрах - мова як мисленнєва форма, мова як інтелектуальна сутність, мова як функція і трансформація свідомості, мова як субстанція культури [10].

Висновки. Мова, безперечно, є чітким відображенням нашого життя, яке, змінюючись, відповідно збагачує і нашу мову значною кількістю новотворів. У нашому дослідженні ми спробували простежити вплив на появу неологізмів сучасних модернізаційних процесів у вітчизняній освіті. Представлений у дослідженні матеріал дає підстави зробити висновок про те, що зміни в освіті, зокрема прийняття Концепції «Нова українська школа», спричинили появу в освітньому середовищі значної кількості неологізмів, невідомих до цього не лише освітянам, а й пересічному українцеві, однак таких, які вільно увійшли у лексикон не лише педагогів, а й здобувачів освіти. Деякі із них не приживуться в нашій мові, застаріють і безслідно зникнуть, а деякі, навпаки, увійдуть до сучасних словників української мови, живої розмовної мови, довівши, що мають право на існування.

Насамкінець хочеться зауважити словами сучасного українського лексикографа Тараса Берези: «Те, що ми не знаємо деяких українських слів та висловів у рідній мові, ще не означає, що їх у ній немає» [1]. Тобто, виникнення новотворів, появу яких зумовили сучасні модернізаційні процеси в освіті, робить Україну впізнаваною у європейському освітньому простоpi, доводить, що вона впевнено крокує у майбутнє, а його, як відомо, творять лише активні та освічені особистості.

\section{СПИСОК ВИКОРИСТАНОЇ ЛІТЕРАТУРИ}

1. Береза Т. Мова - не калька: словник української мови / Т. Береза, І. Зубрицька, Ю. Зелений. Львів : Апріорі, 2014. - 563 с.

2. Бугайчук А. Новий учитель. Перепідготовка / А. Бугайчук. - К. : Шкільний світ, 2018. - 88 с. - (Бібліотека «Шкільного світу»).

3. Гумбольдт В. Избранные труды по языкознанию / В. Гумбольдт ; пер. с нем. - М. : Прогресс, 1984. - 397 c.

4. Колоїз Ж. Українська неологія: здобутки та перспективи / Ж. Колоїз // Наукові праці : науково-методичний журнал : матеріали Всеукр. наук. конфер. «Еволюційні тенденції в мові» (Миколаїв, 15 трав. 2009 р.) / МОН України ; Чорноморський держ. ун-т ім. П. Могили. - Миколаїв : ЧДУ ім. П. Могили, 2009.Т. 105. - Вип. 92. - С. 56-61. - (Серія «Філологія. Мовознавство»).

5. Концепція «Нова українська школа». URL: https://www.kmu.gov.ua/storage/app/media/reforms/ ukrainska-shkola-compressed.pdf (дата звернення: 10.04.2019). 
6. Михальченко М. Політична реальність в Україні: трансформація, модернізація, революція? / М. Михальченко // Сучасна українська політика. Політики і політологи про неї. - К., 2005. - Вип. 7. C. $18-27$.

7. Нова українська школа: порадник для вчителя : навчально-методичні матеріали / за заг. ред. Н. М. Бібік - Київ : ВД «Плеяди», 2017. - 206 c. URL: http://nus.org. ua/wp-content/uploads/2017/11/NUSH-poradnyk-dlyavchytelya.pdf (дата звернення: 10.04.2019).

8. Нові професійні ролі і завдання сучасного вчителя в контексті концепції Нової української школи // Всеосвіта : проект. URL: https://vseosvita.ua/library/ novi-profesijni-roli-i-zavdanna-sucasnogo-vcitela-vkonteksti-koncepcii-novoi-ukrainskoi-skoli-87162.html (дата звернення: 24.03.2019).

9. Скрипник М. Модернізація вітчизняної освіти XXI століття: проблема суб'єктності / М. Скрипник // Методист. - 2018. URL: http://lib.iitta.gov.ua/id/ eprint/709944 (дата звернення: 10.04.2019).

10. Скрипник М. Про мовну тенденцію в модернізації вітчизняної освіти: гра словами чи словесна гра. URL: https://ru.padlet.com/marina_scripnik/ csnocrxeqm7r (дата звернення: 10.04.2019).

Дата надходження до редакиії: 10.09.2019 р.
УДК 373.542

DOI: 10.37026/2520-6427-2019-100-4-100-103
Ірина ОЗАРЧУК,

асистентка кафедри іноземних мов

Національного університету водного господарства та природокористування, м. Рівне

\section{ОСОБЛИВОСТІ ЗДОБУТТЯ ІНШОМОВНОÏ ОСВІТИ В ЗАКЛАДАХ ВИЩОЇ ОСВІТИ КРАЇН БАЛТІЇ}

У статті розкрито особливості здобуття іншомовної освіти в закладах вищзої освіти країн Балтії, зокрема Естонії, Литві, Латвї. Окреслено розвиток іншомовної освіти в иих краӥнах під впливом сучасних інтеграиійних та глобалізаційних прочессів.

Ключові слова: іншомовна освіта, заклади вищоі освіти, іноземна мова, професійна іншомовна освіта, багатомовність.

В статье раскрыты особенности получения иноязычного образования в учреждениях высшего образования стран Балтии, в частности Эстонии, Литве, Латвии. Определено развитие иноязычного образования в этих странах под влиянием современных интеграционных и глобализационных процессов.

Ключевые слова: иноязычное образование, высшие учебные заведения, иностранный язык, профессиональное иноязычное образование, многоязычие.

The article is devoted to the theoretical coverage of the methodological tendencies of the development of higher education. The influence of globalization and internationalization of society on the development of higher foreign education is analyzed. The cognitive, developmental and educational aspects of foreign education in higher schools are characterized.

The article analyzes the development of modern high education in Baltic countries under the influence of the integration and global processes of the late XX th to the beginning of the XXI century. The theoretical approaches to the formation of content of foreign language education in Estonia, Lithuania and Latvia are analyzed. The role of foreign language education at the present stage of functioning of higher education in Baltic countries is revealed. The focus is on the educational objectives of the role of motivation and the need to study and possess more than one foreign language by students is highlighted.

It is proved that the Baltic countries laws contribute to plurilingualism, since the citizens of Estonia, Lithuania and Latvia are multilingual - two thirds of the population are able to speak at least two foreign languages, which is several times higher than the average of the European Union.

The article states that the Baltic countries are guided by the European Recommendations on Language Education: studying, teaching, evaluating the principles outlined in this document and the levels of language proficiency defined by the Council of Europe. The Estonian Lithuanian and Latvian foreign language strategy aims to promote the continuity of teaching and learning foreign languages, as well as the definition and assessment of language skills. Among the many strategic goals, the above issues are priorities in higher education.

Key words: foreign language education, higher education institutions, language, professional foreign language education, multilingualism. 